\title{
Implementasi Nilai-Nilai Tat Twam Asi dalam Pembelajaran dengan Model Problem Based Learning Berpengaruh Positif Terhadap Kompetensi Pengetahuan IPS
}

\author{
1Kadek Agus Sanjaya Pande ${ }^{1 *}$, I Wayan Sujana ${ }^{2}$ (D) \\ ${ }^{12}$ Prodi Pendidikan Guru Sekolah Dasar, Universitas Pendidikan Ganesha, Singaraja, Indonesia \\ *Corresponding author: kadek.agus.sanjaya@undiksha.ac.id
}

\begin{abstract}
Abstrak
Penelitian ini bertujuan untuk mengetahui pengaruh model Problem Based Learning berlandaskan Tat Twam Asi terhadap kompetensi pengetahuan IPS. Penelitian ini adalah penelitian eksperimen semu dengan menggunakan rancangan non equivalent control group design. Populasi penelitian ini berjumlah 229 orang. Penentuan sampel pada penelitian ini menggunakan teknik cluster random sampling dengan pengundian pada kelas yang setara. Kelompok eksperimen berjumlah 30 orang siswa, dan kelompok kontrol berjumlah 35 orang siswa. Data kompetensi pengetahuan IPS dikumpulkan dengan teknik tes bentuk pilihan ganda biasa, dan data dianalisis menggunakan teknik uji-t. Dari hasil analisis diperoleh rata-rata siswa yang dibelajarkan dengan model Problem Based Learning berlandaskan Tat Twam Asi dengan rata-rata gain skor ternormalisasi 0,361 , dan siswa yang dibelajarkan dengan pembelajaran konvensional dengan rata-rata gain skor ternormalisasi 0,280. Hasil uji t diperoleh t_hitung sebesar 2,038, sedangkan nilai t_tabel dengan taraf signifikansi 5\% dengan $\mathrm{dk}=63$ adalah sebesar 1,998. Ini berarti t_hitung > t_tabel $(2,038>1,998)$. Berdasarkan hasil tersebut dapat disimpulkan bahwa terdapat pengaruh model Problem Based Learning berlandaskan Tat Twam Asi terhadap kompetensi pengetahuan IPS siswa.
\end{abstract}

Keywords: Problem Based Learning, Tat Twam Asi

\section{Abstract}

The research was aimed at finding out the effect of Problem Based Learning based on Tat Twam Asi on social science competency. This research is a quasi-experimental research with a non-quivalent control group design. The population is 229 students. The sample used random sampling technique with an equivalent class draw. The experimental group consisted of 30 students, and the control group consisted of 35 students. The data was gathered through multiple choice test technique, and the data analyzed by using t-test technique. The result shows that the student's mean which applied with Problem Based Learning model based on Tat Twam Asi with a gain score was 0,361; and students which applied with conventional learning gain a score was 0,280. The result was obtained t_count 2,038; meanwhile the score t_table with 5\% significant level for dk=63 was 1,998. It means, $t$ _count > t_table $(2,038>1,998)$. Based on the result, it could be concluded that there is an effect of Problem Based Learning based on Tat Twam Asi to social science competency in the fourth-grade students.

Keywords: Problem Based Learning, Tat Twam Asi

\section{Pendahuluan}

Pendidikan merupakan sistem dan tata cara meningkatkan kualitas hidup seseorang pada semua aspek kehidupannya. Melalui pendidikan, manusia dapat mengembangkan potensi yang dimiliki dan mendapatkan pengetahuan. Dari pendidikan maka tercipta banyak hal-hal menakjubkan, seperti kepercayaan, budaya, pengetahuan, seni dan banyak hal lainnya. Didasarkan hal tersebut, pendidikan adalah sesuatu yang vital yang wajib diperoleh setiap individu.

Pemerintah telah merumuskan secara ringkas dan padat mengenai penjelasan pendidikan yang tertuang di Undang Undang No. 20 Tahun 2003 tentang Sistem Pendidikan Nasional, yang berbunyi : pendidikan adalah usaha sadar dan terencana untuk mewujudkan suasana belajar dan proses pembelajaran agar siswa secara aktif mengembangkan potensi dirinya untuk memiliki kekuatan spiritual keagamaan, pengendalian diri, kepribadian,

History:
Received : 4 Maret 2020
Revised : 11 Juli 2020
Accepted : 20 Agutus 2020
Published : 25 September 2020

Publisher: Undiksha Press

Licensed: This work is licensed under

a Creative Commons Attribution 3.0 License

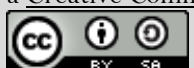


kecerdasan, akhlak mulia, serta keterampilan yang diperlukan dirinya, masyarakat, bangsa dan Negara. Untuk itu peningkatan kualitas guru memegang peranan yang teramat penting. Selain itu guru pada pelaksanakan pendidikan perlu adanya suatu kurikulum yang dapat mendukung proses pendidikan yang baik. Peranan guru amatlah penting dalam menentukan kualitas pendidikan suatu bangsa. Untuk itu peningkatan kualitas guru memegang peranan yang teramat penting. Selain itu guru pada pelaksanakan pendidikan perlu adanya suatu kurikulum yang dapat mendukung proses pendidikan yang baik (Yuniarti, 2018).

Dalam sistem pendidikan di Indonesia, telah beberapa kali dilakukan perubahan kurikulum. Wahyudi dan Siswanti (2015) menyebutkan, kurikulum berkembang dinamis sesuai dengan perkembangan jaman, tuntutan masyarakat, tantangan yang ada di masyarakat dan kebutuhan masyarakat. Saat ini kurikulum yang diterapkan adalah Kurikulum 2013, yang merupakan penyempurnaan dari Kurikulum Tingkat Satuan Pendidikan (KTSP). Kurikulum 2013 memiliki ciri yaitu menuntut kemampuan seorang pendidik dalam berpengetahuan dan mampu mencari tahu pengetahuan sebanyak-banyaknya karena siswa jaman sekarang telah mudah mencari informasi-informasi dengan bebas melalui perkembangan teknologi dan informasi yang ada. Agustino (2017) menyatakan, Kurikulum 2013 menghendaki terciptanya kompetensi yang berimbang antara sikap, pengetahuan, dan keterampilan.

Keberhasilan dalam belajar pada kurikulum 2013 disebut kompetensi. "Kompetensi adalah perpaduan dari pengetahuan, keterampilan, nilai dan sikap yang direfleksikan dalam kebiasaan berpikir dan bertindak" (Sanjaya, 2013:70). Menurut Yusuf (2015:263) "kompetensi merupakan perpaduan skill, tingkah laku dan pengetahuan serta nilai-nilai dasar yang dapat didemonstrasikan atau direfleksikan dalam kebiasaan dan kemampuan berpikir dan bertindak siswa sebagai yang dicapai melalui kegiatan mengajar bermakna dan penuh arti”.

Dalam kurikulum 2013 siswa dituntut untuk lebih aktif, kreatif, dan inovatif dalam setiap pemecahan masalah yang mereka hadapi di sekolah. Dalam kurikulum 2013 selain dinilai dari pengetahuan, siswa juga dinilai dari keterampilan, dan sikap siswa. Puspitasari (2020), menyatakan seiring dengan pelaksanaan kurikulum 2013 khususnya di SD yang sudah berjalan sampai saat ini diharapkan adanya perubahan pelaksanaan pembelajaran untuk mengubah pola pikir dan strategi guru dalam mengajar yang sebelumnya berpusat pada guru menjadi berpusat pada siswa.

Pendidikan erat kaitannya dengan proses belajar. Belajar merupakan salah satu cara untuk menambah wawasan dan pengetahuan seseorang. "Belajar dapat didefinisikan sebagai suatu proses yaitu suatu organisme berubah perilakunya sebagai akibat pengalaman" Gagne (dalam Susanto, 2013:1). Jadi belajar merupakan suatu hal yang sangat penting bagi siswa untuk menambah pengetahuannya sehingga mampu mendukung terciptanya mutu pendidikan yang lebih baik dan berkualitas. Oleh karena itu, hendaknya seorang pendidik membelajarkan siswa melalui pengalaman-pengalaman yang siswa dapatkan dalam kehidupan sehari-hari. Dalam proses pembelajaran khususnya di sekolah dasar siswa diajarkan pembelajaran tematik integratif yang salah satu materi muatannya adalah Ilmu Pengetahuan Sosial (IPS).

Ilmu Pengetahuan Sosial merupakan ilmu pengetahuan yang membahas bermacammacam bidang ilmu sosial dan humaniora yang dijadikan satu dalam upaya memberikan pandangan yang terperinci siswa (Susanto, 2013). Selain itu, IPS dapat dikatakan sebagai gabungan dari berbagai disiplin ilmu (interdisipliner) artinya, IPS mengambil disiplin ilmu sosial seperti geografi, antropologi, arkeologi, ekonomi, hukum, ilmu politik, dan ilmu kemanusiaan. Fajrin (2018) menyatakan bahwa matan materi IPS akan berguna bagi peserta didik dalam bermasyarakat, menghadapai tantangan zaman dan permasalahan sosial. Di sekolah secara khusus dalam pembelajaran IPS diperlukan suasana yang menyenangkan agar tidak timbul suasana yang membosankan karena siswa dituntut lebih banyak membaca serta memahami materi yang diberikan oleh gurunya (Dewi, 2014). Lebih 
lanjut, Saraswati (2020) menyatakan, sesuai dengan tujuan pendidikan yang mengharapkan terwujudnya manusia yang memiliki potensi dalam diri dan memiliki keterampilan dalam bermasyarakat berbangsa dan bernegara, maka pada kurikulum 2013 kompetensi yang membantu terwujudnya hal tersebut adalah kompetensi pengetahuan IPS.

Berdasarkan hasil observasi yang dilakukan saat pelaksanaan PPL-Real di salah satu sekolah dasar di Denpasar, permasalahan yang dihadapi adalah nilai IPS siswa masih belum optimal. Dalam proses pembelajaran siswa kurang aktif dan dapat menyebabkan suasana pembelajaran kurang kondusif, senada dengan pendapat Hermayanti (2018) bahwa "suasana pembelajaran menjadi tidak kondusif sehingga siswa menjadi pasif". Serta siswa masih perlu bantuan dari guru untuk memecahkan suatu permasalahan, dikarenakan kemampuan pemecahan masalah sangat berperan penting dalam proses belajar siswa, sependapat dengan Cahyani (2019) menyatakan "kemampuan pemecahan masalah yang baik pada siswa dapat meningkatkan hasil belajar siswa. Oleh karena itu, kondisi pembelajaran diarahkan untuk mendorong siswa mencari tahu dari berbagai sumber (observasi), mampu merumuskan masalah (menanya) bukan hanya menyelesaikan masalah (Hosnan, 2016)

Dalam proses pembelajaran guru memegang peranan yang sangat penting untuk menciptakan suatu proses pembelajaran yang aktif dan interaktif (Christiana, 2014). Maka dari itu, perlu diterapkan sebuah model pembelajaran yang dapat membantu ketercapaian proses pembelajaran itu sendiri, dengan menerapkan model pembelajaran maka siswa bisa lebih mudah memahami materi serta semakin bersemangat dalam mengikuti pembelajaran. Model pembelajaran yang bisa dijadikan sebagai alternatif untuk menyelesaikan persoalan tersebut yaitu model Problem Based Learning (pembelajaran berbasis masalah). Menurut Widayati (2012) pembelajaran berbasis masalah adalah suatu model pembelajaran yang pelaksanaannya memicu siswa secara aktif menuntaskan permasalahan konstektual. Dalam pelaksanaannya, model pembelajaran ini dapat diterapkan kepada siswa secara berkelompok atau secara mandiri. Problem Based Learning merupakan model pembelajaran inovatif yang dapat memberikan kondisi belajar aktif kepada siswa. Dimana siswa dapat secara aktif berfikir dalam menyelesaikan masalah yang berkaitan dengan kehidupan sosial mereka (Dewi, 2013).

Pembelajaran berbasis masalah kerap diidentikkan dengan pendekatan pembelajaran konstektual yang mengarahkan siswa agar mampu menumbuhkan keterampilannya dalam memecahkan suatu permasalahan menentukan keputusan atas permasalahan tersebut. Model pembelajaran Problem Based Learning (PBL) selain membantu siswa memahami konsepkonsep yang sulit, juga berguna untuk membantu siswa untuk mengembangkan keterampilan menyelesaikan masalah dan berpikir kritis serta dapat bekerja sama dalam memecahkan permasalahan sekaligus membangun pengetahuan baru secara berpasangan atau berkelompok (Ariswati, 2018). Di dalam Problem Based Learning guru lebih berperan sebagai pembimbing dan fasilitator sehingga siswa belajar berpikir dan memecahkan masalah mereka sendiri (Diantari, 2014).

Pada permulaan pembelajaran berbasis masalah dijadikan sebagai usaha untuk membantu siswa mengartikan pengetahuan suatu konsep. Sebagai contoh siswa belajar tentang suatu materi secara teoretis serta menghubungkan dengan permasalahan di lingkungannya yang terkait dengan materi tersebut serta berupaya memecahkan masalah yang ada. Penerapan model Problem Based Learning dapat dipadukan dengan konsep Tat Twam Asi dengan harapan mampu meningkatkan rasa saling menghargai antar siswa. Pradnyani (2017) menyatakan Pembelajaran Quantum dipadukan dengan kearifan lokal Tat Twam Asi membuat siswa lebih disiplin dalam proses pembelajaran menjadi lebih bermakna. Hal itu karena pembelajaran quantum dipadukan dengan kearifan lokal Tat Twam Asi menekankan kepada siswa untuk membangun pengetahuannya sendiri dengan menekakankan toleransi dalam pelaksanaan pembelajaran, contoh-contoh yang diberikan dalam 
pembelajaran dapat dialami langsung oleh siswa itu sendiri. Sependapat dengan pernyataan tersebut Adnyana (2017) menyatakan pembelajaran menggunakan model pembelajaran role playing berbasis Tat Twam Asi pada muatan materi IPS memberikan kesempatan yang lebih luas kepada siswa untuk mengonstruksikan pengetahuannya melalui berbagai kegiatan bermakna dan teratur yang tentunya menggembirakan bagi: siswa pada setiap langkah pembelajarannya.

Dalam kegiatan pembelajaran di kelas, konsep Tat Twam Asi perlu ditanamkan agar situasi pembelajaran menjadi harmonis. Menurut Subagiasta (2007) salah satu sumber ajaran mengenai etika pendidikan yang ada pada masyarakat di Bali yaitu kearifan lokal Tat Twam Asi. Tat Twam Asi memiliki makna, aku adalah kamu, kamu adalah aku. Artinya dalam bertindak seseorang diminta untuk selalu hidup rukun terhadap sesama dengan senantiasa saling menghargai dan menghormati serta selalu menjunjung tinggi rasa toleransi terhadap setiap orang. Maka dari itu, sudah sepatutnya kita dilarang menyakiti satu sama lain. Apriliani dan Yudiana (2020) menyatakan secara umum, kearifan lokal Tat Twam Asi memiliki makna mengganggap semua orang sama. Jika seseorang tidak menghormati orang lain maka itu sama artinya dengan tidak menghormati diri sendiri. Dalam proses pembelajaran di dalam kelas, menjaga kerukunan dan antar sesasama dapat diterapkan melalui menolong teman yang mengalami kesulitan, dan belajar bersama.

Dalam model Problem Based Learning berlandaskan Tat Twam Asi siswa dituntut untuk mampu berpikir secara kritis serta memiliki sikap sosial tentang kepedulian terhadap sesama. Dengan berpikir kritis siswa memungkinkan melakukan pertimbangan secara tepat dan cermat sebelum mengambil sebuah keputusan. Kemampuan berpikir kritis adalah kemampuan yang dimiliki oleh seseorang untuk dapat berpikir tingkat tinggi terutama dalam memecahkan suatu permasalahan agar dapat mengambil keputusan yang tepat dan logis untuk menyelesaikan maupun memecahkan permasalahan tersebut (Asriningtyas, 2018). Keterampilan berpikir kritis yang dimiliki peserta didik sangat berguna bagi kehidupan nyata dimana kehidupan penuh tantangan yang datang baik dalam kehidupan sehari-hari maupun tantangan dalam dunia kerja karena siswa memiliki pola pikir yang terbuka, reflektif, kritis, belajar aktif, memecahkan masalah, komunikasi, kerja kelompok, dan keterampilan interpersonal dengan lebih baik (Haryanti, 2017). Dalam pelaksanaan pembelajaran, setiap langkah pembelajaran menerapkan konsep kearifan lokal Tat Twam Asi. Dengan berlandaskan Tat Twam Asi, pembelajaran dengan model Problem Based Learning akan membuat siswa menjadi saling menghargai satu sama lain dan suasana pembelajaran menjadi menyenangkan.

Tujuan penelitian ini adalah untuk menganalisis pengaruh model problem based learning berlandaskan tat twam asi terhadap kompetensi pengetahuan IPS siswa.

\section{Metode}

Tempat pelaksanaan penelitian ini adalah di SDN Gugus Dr. Soetomo, Kecamatan Denpasar Selatan yang terdiri dari 4 sekolah, dengan jumlah kelas sebanyak 6 kelas. Adapun kelas yang dijadikan sebagai kelas eksperimen adalah kelas IVA SDN 12 Sesetan dan kelas yang dijadikan kelas kontrol adalah kelas IVB SDN 9 Sesetan. Penelitian dilakukan pada semester genap tahun ajaran 2019/2020, dan penelitian ini dimulai pada bulan Februari 2020 hingga bulan Maret 2020. Penelitian ini memakai quasi eksperiment (eksperimen semu). Rancangan eksperimen yang digunakan adalah "Nonequivalent kontrol grup design" yang menggunakan kelompok eksperimen maupun kelompok kontrol.

Dalam setiap penelitian yang dilakukan, populasi dan sampel mempunyai peran yang sangat penting karena dijadikan sebagai subjek dalam penelitian. Populasi adalah sesuatu yang memiliki kualitas dan karakteristik tertentu yang terdiri dari obyek/subyek serta ditetapkan oleh peneliti untuk dipelajari dan kemudian ditarik kesimpulannya 
(Sugiyono,2016). Menurut Koyan (2012:30) menyatakan bahwa "populasi adalah himpunan dari unsur-unsur yang sejenis". Berdasarkan pemaparan tersebut dapat dirangkum bahwa populasi merupakan sejumlah individu yang dijadikan sebagai subyek/obyek dalam melakukan penelitian yang memiliki kriteria tertentu. Populasi dari penelitian yang digunakan dalam penelitian ini adalah keseluruhan siswa kelas IV SDN Gugus Dr. Soetomo Kecamatan Denpasar Selatan dengan total jumlah 229 siswa. Dari populasi tersebut dapat diambil sampel yang mewakili karakteristik dari populasi yang ditelliti. Setelah mengetahui populasi langkah selanjutnya adalah menentukan sampel penelitian. Sampel merupakan bagian dari populasi yang ada yang nantinya akan dijadikan sebagai obyek untuk penelitian. Sampel merupakan sebagian karakteristik yang dimiliki oleh populasi tersebut (Sugiyono, 2016). Sedangkan Koyan (2012:30) menyebutkan "sampel penelitian merupakan bagian dari populasi". Dari uraian tersebut dapat disimpulkan bahwa sampel merupakan sebagian dari jumlah dan karakteristik populasi yang dianggap mewakilkan seluruh populasi dengan teknik tertentu. Penentuan sampel dilakukan dengan cara teknik sampling. Pengambilan sampel pada penelitian ini menggunakan teknik random sampling yaitu dengan undian. Berdasarkan hasil pengundian diperoleh 2 kelas yang masing-masing dijadikan kelas eksperimen dan kelas kontrol yang merupakan sampel penelitian.

Dari 6 kelas, dilakukan dua kali pengundian. Pengundian tahap pertama untuk memilih dua kelas yang dijadikan sampel penelitian. Kedua kelas sampel tersebut selanjutnya kembali melakukan pengundian untuk dijadikan kelas eksperimen dan kelas kontrol. Berdasarkan pengundian yang dilakukan, kelas yang muncul pertama dan akan dijadikan sebagai kelas eksperimen, dan kelas yang muncul kedua akan dijadikan sebagai kelas kontrol. Pada kelas eksperimen diberikan perlakuan berupa model Problem Based Learning berlandaskan Tat Twam Asi dan untuk kelas kontrol dibelajarkan menggunakan pembelajaran konvensional. Untuk menperoleh kelas dengan kemampuan akademik yang sama, maka kedua kelas yang terpilih menjadi sampel penelitian diberikan pre-test. Untuk menentukan kesetaraan pada kelas eksperimen dan kelas kontrol, nilai dari hasil pre-tes diuji dengan rumus uji-t.

Hasil atau data penelitian sangat tergantung pada jenis alat (instrumen) pengumpulan datanya. Data yang dianalisis dalam penelitian ini adalah data kompetensi pengetahuan bermuatan materi IPS, dan untuk mendapat data tersebut digunakan tes. Tes merupakan cara atau teknik yang digunakan sebagai alat ukur sesuatu dengan cara yang telah ditetapkan (Arikunto, 2016). Senada dengan pendapat Gronlund dan Linn (dalam Koyan, 2011) menyatakan bahwa tes merupakan salah satu instrumen atau langkah yang teratur sebagai alat ukur suatu perilaku tertentu. Jenis tes yang digunakan dalam penelitian ini adalah tes objektif. Tes yang pada penelitian digunakan sebagai alat ukur kompetensi pengetahuan IPS berbentuk tes pilihan ganda atau tes objektif meliputi 4 pilihan jawaban (a, b, c atau d) dilakukan pengujian instrumen yaitu uji validitas, daya beda, tingkat kesukaran, dan reliabilitas.

Metode analisis data yaitu metode analisis statistik inferensial. Cara analisis data merupakan teknik analisis statistik inferensial serta uji t. Ada dua syarat yang dilalui sebelum uji t yaitu uji normalitas sebaran data serta uji homogenitas varians. Apabila data didapatkan telah terpenuhinya prasyarat uji normalitas serta homogenitas sehingga pada uji hipotesis analisis yang digunakan statistik parametrik. Analisis statistik dipakai yaitu uji beda mean (uji t).

\section{Hasil dan Pembahasan}

Data gain score kompetensi pengetahuan IPS kelompok eksperimen yang diberi perlakuan berupa model Problem Based Learning berlandaskan Tat Twam Asi mendapatkan rata-rata (means) sebesar 0,361, standar deviasi sebesar 0,178, varians sebesar 0,032, gain skor maksimum sebesar 0,67, dan gain skor minimum sebesar 0,10. Sedangkan, data gain 
score kompetensi pengetahuan IPS kelompok Kontrol yang diberi perlakuan pembelajaran pembelajaran konvensional. Menurut pemaparan Tabel tersebut didapatkan rata-rata (means) sebesar 0,280, standar deviasi sebesar 0,134, varians sebesar 0,018, gain skor maksimum sebesar 0,71, dan gain skor minimum sebesar 0,07.

Tabel 1. Rekapitulasi Hasil Analisis Post-test Kompetensi Pengetahuan IPS

\begin{tabular}{lcc}
\hline \multirow{2}{*}{ Statistik } & \multicolumn{2}{c}{ Kompetensi Pengetahuan IPS } \\
\cline { 2 - 3 } & Kelompok Eksperimen & Kelompok Kontrol \\
\hline Rata-Rata $(\overline{\mathrm{X}})$ & 0,361 & 0,280 \\
Standar Deviasi $(\mathrm{S})$ & 0,178 & 0,134 \\
Varians $\left(\mathrm{S}^{2}\right)$ & 0,032 & 0,018 \\
Skor Tertinggi & 0,67 & 0,71 \\
Skor Terendah & 0,10 & 0,07 \\
\hline
\end{tabular}

Salah satu uji prasyarat analisis yaitu uji normalitas sebaran data. Uji normalitas dilaksanakan guna mengetahui sebaran data dari skor kompetensi pengetahuan IPS siswa kelompok eksperimen maupun kontrol berdistribusi normal atau tidak. Uji normalitas sebaran data pada penelitian ini menggunakan uji Kolmogorov-Smirnov, dengan menggunakan taraf signifikansi 5\% yaitu apabila nilai $\mid$ FT - FS $\mid$ terbesar $\leq$ nilai tabel Kolmogorov-Smirnov, oleh karena itu data dapat dinyatakan berdistribusi normal. uji normalitas sebaran data kelompok eksperimen diperoleh harga nilai maksimum $\left|\mathrm{F}_{\mathrm{T}}-\mathrm{F}_{\mathrm{S}}\right|=0,101<$ harga nilai tabel kolmogorov-smirnov $=0,218$, maka sebaran data dari data gain skor ternormalisasi kompetensi pengetahuan IPS kelompok eksperimen berdistribusi normal. Pada kelompok kontrol harga nilai maksimum $\left|\mathrm{F}_{\mathrm{T}}-\mathrm{F}_{\mathrm{S}}\right|=0,089<$ harga nilai tabel kolmogorov-smirnov = 0,202 maka sebaran data dari data gain skor ternormalisasi kompetensi pengetahuan IPS kelompok kontrol dinyatakan berdistribusi normal.

Tabel 2. Hasil Uji Normalitas Kelompok Eksperimen dan Kelompok Kontrol

\begin{tabular}{llcccc}
\hline No & Kelompok Sampel & $\begin{array}{c}\text { Jumlah } \\
\text { Sampel }\end{array}$ & $\begin{array}{c}\text { Nilai } \\
\text { Maksimum } \\
\mid \text { FT - Fs }\end{array}$ & $\begin{array}{c}\text { Nilai Tabel } \\
\text { Kolmogorov- } \\
\text { Smirnov }\end{array}$ & Kesimpulan \\
\hline 1 & Kelompok Eksperimen & 30 & 0,101 & 0,218 & Berdistribusi Normal \\
2 & Kelompok Kontrol & 35 & 0,089 & 0,202 & Berdistribusi Normal \\
\hline
\end{tabular}

Langkah selanjutnya pada uji prasyarat analisis adalah uji homogenitas varians. Uji homogenitas varians dilakukan terhadap data perolehan dari kedua kelompok. Tujuan dari dilakukannya uji homogenitas varians adalah untuk mengetahui varians homogen atau tidak. Pada uji homogenitas varians dipergunakan rumus yaitu dengan menggunakan uji $\mathrm{F}$ (fisher). Berdasarkan hasil perhitungan diperoleh harga $F_{\text {hitung }}=1,75$, angka itu selanjutnya dibandingkan dengan harga $\mathrm{F}_{\text {tabel }}$ dengan taraf signifikansi $5 \%(\alpha=0,05)$ dengan dk untuk pembilang yaitu 30-1 = 29 dan dk untuk penyebut 35-1 = 34, sehingga dapat diperoleh $\mathrm{F}_{\text {tabel }}=$ 1,85, maka dari itu data gain skor ternormalisasi kompetensi pengetahuan IPS dari kedua kelas dinyatakan mempunyai varians yang homogen.

Tabel 3. Uji Homogenitas Varians

\begin{tabular}{|c|c|c|c|c|c|c|}
\hline No & Sampel & Varians & Dk & $F_{\text {hitung }}$ & $F_{\text {tabel }}$ & Kesimpulan \\
\hline 1 & Kelas Eksperimen & 0,032 & 29 & 175 & 185 & \\
\hline 2 & Kelas Kontrol & 0,011 & 34 & $1, / 5$ & 1,85 & Homogen \\
\hline
\end{tabular}


Setelah dilaksanakannya uji normalitas sebaran data maupun uji homogenitas varians diperoleh data yang berasal dari kedua kelompok dinyatakan berdistribusi normal dan mempunyai varians yang homogen. Maka dari itu, diperolehlah data yang sudah memenuhi uji prasyarat analisis, selanjutnya dapat dilaksanakan uji hipotesis yang menggunakan analisis uji-t yang digunakan adalah rumus polled varians. Kriteria pengujian dari uji-t yaitu jika $t_{\text {hitung }} \leq t_{\text {tabel }}$, dinyatakan $H_{o}$ diterima. Seandainya jika $t_{\text {hitung }}>t_{\text {tabel }}$, dinyatakan $\mathrm{H}_{\mathrm{o}}$ ditolak, dengan $\mathrm{dk}=\mathrm{n} 1+\mathrm{n} 2-2$ pada taraf signifikansi $5 \%(\alpha=0,05)$.

Berdasarkan hasil perhitungan dan tabel rekapitulasi hasil analisis uji-t, didapatkan $\mathrm{t}_{\text {hitung }}=2,038$ pada taraf signifikansi $5 \%$ dengan $\mathrm{dk}=(30+35-2)=63$ didapatkan $\mathrm{t}_{\text {tabel }}$ 1,998. Dengan kriteria $t_{\text {hitung }}=2,038>t_{\text {tabel }}=1,998$ oleh karena itu, $H_{o}$ ditolak dan $\mathrm{H}_{a}$ diterima. Berdasarkan hasil analisis diketahui perbedaan yang signifikan kompetensi pengetahuan IPS siswa kelas eksperimen yang dibelajarkan dengan model Problem Based Learning berlandaskan Tat Twam Asi dengan kelas kontrol yang dibelajarkan dengan pembelajaran konvensional, dengan kata lain variabel bebas yaitu model Problem Based Learning berlandaskan Tat Twam Asi memiliki pengaruh terhadap variabel terikat yaitu kompetensi pengetahuan IPS siswa kelas IV SDN Gugus Dr. Soetomo Kecamatan Denpasar Selatan.

Dari analisis data kompetensi pengetahuan IPS yang telah dilaksanakan didapatkan nilai rata-rata pada kelompok eksperimen $=0,361$. Berdasarkan hasil perhitungan data gain score ternormalisasi kompetensi pengetahuan IPS, menunjukkan bahwa rata-rata gain score ternormalisasi kelompok eksperimen lebih dari rata-rata gain score ternormalisasi kelompok kontrol.

Tabel 4. Uji Hipotesis

\begin{tabular}{clccccccc}
\hline No & \multicolumn{1}{c}{ Sampel } & $\mathbf{N}$ & $\mathbf{D k}$ & $\overline{\mathbf{X}}$ & $\mathbf{S}^{\mathbf{2}}$ & thitung & ttabel & Simpulan \\
\hline 1 & Kelas Eksperimen & 30 & \multirow{2}{*}{63} & 0,361 & 0,032 & \multirow{2}{*}{2,038} & \multirow{2}{*}{1,998} & \multirow{2}{*}{$\mathrm{H}_{\mathrm{o}}$ ditolak } \\
2 & Kelas Kontrol & 35 & & 0,280 & 0,018 & & & \\
\hline
\end{tabular}

Terdapat kesamaan temuan antara penelitian ini dengan penelitian yang sudah pernah dilaksanakan sebelumnya oleh peneliti lain dan bertujuan memperkuat hasil penelitian yang didapat pada penelitian ini. Salah satunya yaitu Santiani (2017) yang menunjukkan nilai ratarata hasil belajar IPS kelompok eksperimen yaitu 20,45, sementara nilai rata-rata hasil belajar IPS kelompok kontrol yaitu 15,31. Kelompok eksperimen diberikan perlakuan dalam pembelajaran berupa model Problem Based Learning berbantuan media konkret. Sementara pada kelompok kontrol dibelajarkan dengan pembelajaran konvensional. Jadi model Problem Based Learning berbantuan media konkret berpengaruh positif terhadap hasil belajar IPS.

\section{Simpulan}

Berdasarkan penelitian yang telah dilaksanakan maka dapat ditarik simpulan yaitu terdapat perbedaan yang signifikan antara kelompok siswa yang dibelajarkan dengan model Problem Based Learning berlandaskan Tat Twam Asi dengan kelompok siswa yang dibelajarkan dengan pembelajaran konvensional. Adapun saran kepada pihak-pihak terkait yaitu (1) Kepada guru, Guru hendaknya menjadikan hasil penelitian ini sebagai bahan pertimbangan dalam menyusun perencanaan pembelajaran kerena hasil penelitian ini menunjukkan bahwa terdapat pengaruh yang signifikan Problem Based Learning berlandaskan Tat Twam Asi terhadap Kompetensi Pengetahaun IPS siswa. , (2) Kepada kepala sekolah, Bersumber pada hasil temuan yang didapatkan pada penelitian ini, kepala sekolah diharapkan menyarankan untuk dapat menggunakan penelitian ini sebagai referensi kepada guru lain untuk menggunakan model pembelajaran untuk meningkatkan hasil belajar 
siswa, (3) Kepada peneliti lain, Kepada peneliti diharapkan menjadikan penelitian ini sebagai acuan dan referensi untuk mendapatkan informasi agar memperoleh hasil yang lebih baik ke depann.

\section{Daftar Pustaka}

Adnyana, Made Wira. (2017) "Pengaruh Model Pembelajaran Role Playinng Berbasis Tat Twam Asi Terhadap Penguasaan Kompetensi Pengetahuan IPS”. EJournal PGSD Universitas Pendidikan Ganesha Mimbar PGSD. Volume 1, Nomor 4.

Agustino, I Kadek. (2017). Pengaruh Model Pembelajaran Inkuiri Berbasis Penilaian Kinerja Terhadap Kompetensi Pengetahuan IPA Siswa Kelas IV Gugus IX Abiansemal Kecamatan Abiansemal Tahun Pelajaran 2016/2017. Jurnal Mimbar PGSD UNDIKSHA. Volume 5. Nomor 1.

Apriliani, P.A.S. dan Yudiana, Kadek. (2020) Model Pembelajaran Doll Speak Berbasis Kearifan Lokal Tat Twam Asi Terhadap Sikap Toleransi Siswa. Jurnal Mimbar PGSD UNDIKSHA. Volume 8. Nomor 2.

Arikunto, Suharsimi. 2016. Dasar-Dasar Evaluasi Pendidikan. Jakarta: PT Bumi Aksara

Asriningtyas, Anastasia Nandhita. (2018). Penerapan Model Pembelajaran Problem Based Learning Untuk Meningkatkan Kemampuan Berpikir Kritis Dan Hasil Belajar Matematika Siswa Kelas 4 SD. Jurnal Karya Pendidikan Matematika Universitas Muhammadiyah Semarang. Volume 5, Nomor 1.

Cahyani, Dian Sisvina. (2019). Pengaruh Model Pembelajaran Creative Problem Solving Terhadap Kemampuan Pemecahan Masalah Matematis Siswa. Jurnal Mimbar PGSD UNDIKSHA. Volume 7, Nomor 2.

Christiana, Putu Pande. (2014). Pengaruh Model Problem Based Learning Berbasis Penilaian Proyek Terhadap Kemampuan Berpikir Kritis IPA SD Gugus VIII Sukawati. Jurnal Mimbar PGSD UNDIKSHA. Volume 2. Nomor 1.

Dewi, N. P. A. M. dkk. (2013). Pengaruh Model Pembelajaran Problem Based Learning (PBL) Berbantuan Media Video Terhadap Hasil Belajar IPA Kelas IV SD Negeri Pergung. Jurnal Mimbar PGSD UNDIKSHA.Volume 1, Nomor 1.

Dewi, P. A. S. (2014). Pengaruh Model Problem Based Learning Berbantuan Media Cetak Terhadap Hasil Belajar Ips Siswa Kelas V SD Gugus V Mengwi. Jurnal Mimbar PGSD UNDIKSHA. Volume 2, Nomor 1.

Diantari, Putu. (2014). Pengaruh Model Pembelajaran Problem Based Learning Berbasis Hypnoteaching Terhadap Hasil Belajar Matematika Siswa Kelas V SD. Jurnal Mimbar PGSD UNDIKSHA. Volume 2. Nomor 1.

Fajrin, Oktaviastuti Awalia. (2018). Pengaruh Model Talking Stick terhadap Hasil Belajar IPS Siswa SD. Jurnal Bidang Pendidikan Dasar. Volume 2. Nomor 1A.

Haryanti, Dwi Yuyun. (2017). Model Problem Based Learning Membangun Kemampuan Berpikir Kritis Siswa Sekolah Dasar. Jurnal Cakrawala Pendas. Volume 3, Nomor 2.

Hermayanti, Putu. (2018). "Pengaruh Model Pembelajaran Kooperatif Tipe Team Games Tournament Berbantuan Peta Konsep Terhadap Hasil Belajar IPA”. Jurnal Ilmiah Sekolah Dasar UNDIKSHA. Volume 2, Nomor 2.

Hosnan, M. (2016). Pendekatan Saintifik dan Kontekstual dalam Pembelajaran Abad 21. Bogor: Ghalia Indonesia. 
Implementasi Nilai-Nilai Tat Twam Asi dalam Pembelajaran dengan Model Problem Based Learning Berpengaruh Positif Terhadap Kompetensi Pengetahuan IPS

Koyan, I. Wayan . 2011. Asesmen Dalam Pendidikan. Singaraja: Universitas Pendidikan Ganesha

Koyan, I. Wayan. 2012. Statistik Pendidikan Teknik Analisis Data Kuantitatif. Singaraja: Universitas Pendidikan Ganesha Press.

Puspitasari, Risky Priliani. (2020). Pengaruh Model Problem Based Learning terhadap Kemampuan Berpikir Tingkat Tinggi dan Hasil Belajar Siswa Kelas V SD. Jurnal Pendidikan. Volume 5, Nomor 4.

Sanjaya, Wina. 2013. Strategi Pembelajaran Berorientasi Standar Proses Pendidikan. Jakarta: Kencana

Santiani, Ni Wayan. (2017). "Pengaruh Model Pembelajaran Problem Based Learning Berbantuan Media Konkret Terhadap Hasil Belajar IPA Siswa Kelas V SD”. $e$ Journal PGSD Universitas Pendidikan Ganesha Mimbar PGSD, Volume 5, Nomor 2.

Saraswati, Putu Indah. (2020). Kontribusi Kecerdasan Interpersonal dan Sikap Ingin Tahu Terhadap Kompetensi Pengetahuan IPS Jurnal Mimbar PGSD UNDIKSHA. Volume 8 , Nomor 1.

Subagiasta, I Ketut. 2007. Etika Pendidikan Agama Hindu. Surabaya:Paramita.

Sugiyono. 2016. Metode Penelitian Pendidikan. Bandung: Alfabeta.

Susanto, Ahmad. 2013. Teori Belajar dan Pembelajaran Di Sekolah Dasar. Jakarta: Kencana Prenada Media Group.

Undang-Undang Republik Indonesia Nomor 20 Tahun 2003 tentang Sistem Pendidikan Nasional. 2003. Jakarta: Presiden Republik Indonesia. diakses pada tanggal: 3 Oktober 2019

Wahyudi dan Siswanti, Mia Christy. (2015) Pengaruh Pendekatan Saintifik Melalui Model Discovery Learning Dengan Permainan Terhadap Hasil Belajar Matematika Siswa Kelas 5 SD. Jurnal Pendidikan dan Kebudayaan. Volume 5. Nomor 3

Widayati, Ninik Sri dan Muaddab, Hafiz. 2012. 29 Model-Model Pembelajaran Inovatif. Surabaya : CV Garuda Mas Sejahtera

Yuniarti, Dwi. (2018). Pengaruh Model Student Teams Achievement Divisions (STAD) Berbantuan Media Mind Mapping Terhadap Hasil Belajar IPS Siswa Kelas V SD Gugus III Kuta Utara Badung Tahun Ajaran 2017/2018. Jurnal Mimbar PGSD UNDIKSHA. Volume 6. Nomor 1. 